\title{
DRIEKANT POMENI TRIKOTNIK
}

V

nizozemščini »driekant « pomeni trikotnik. Za kakšen trikotnik gre? Tisti sloviti trikotnik, ki ga zdaj poskušamo vzpostaviti tudi v Sloveniji in v katerem delujejo $\mathrm{z}$ roko $\mathrm{v}$ roki: država, zasebni sektor in civilna družba. V tem trikotniku si vsi s skupnimi močmi prizadevajo doseči boljši družbeni in ekonomski razvoj in boljše življenje ljudi.

Driekant pa je tudi ime izobraževalnega centra za odrasle, ki ima svoj sedež nekje v bližini Nimegna, na komaj zaznavni vzpetini sredi značilne nizozemske ravnine. Ko se cesta prav rahlo povzpne, vam nizozemski sogovorniki in sopotniki ne pozabijo povedati, da ste prispeli v gore.

Driekant je torej »na gori « in prvi vtis je vtis o skromnem skupku hiš in zabojnikov. $\mathrm{V}$ hišah seveda nudijo prenočišče seminaristom, v zabojnikih skoraj nikoli ne ugasnejo računalnikov, predavalnice so pravzaprav majhni prostori za učenje, ki poteka v razgovoru z mentorjem. Vse naokrog pa so prastara drevesa in med njimi v dvojicah ali skupinicah sedijo seminaristi in razglabljajo o študijskih vprašanjih. Različnim generacijam pripadajo pa tudi različnih poklicev so: od policijskih inšpektorjev, aktivistov $v$ mladinskih klubih pa vse do odraslih v tretjem življenjskem obdobju.

V svojem razvoju je bil Driekant značilno odvisen tako od stanja v izobraževanju odraslih kot od družbenega razvoja v državi. $\mathrm{Ob}$ tem mi sežejo v misel še nekatere nizozemske posebnosti: $\mathrm{v}$ nasprotju z nekaterimi drugimi državami, je Nizozemska poznana po tesni povezavi med izobraževanjem odraslih in socialnim delom, slednje pa je lahko pomembna opora družbenemu razvoju. ${ }^{1}$ Še več, tudi andragogika je v tej deželi veda o izobraževanju odraslih in hkrati veda o družbenem razvoju. Tako andragog največkrat ni le nekdo, ki lahko svetuje glede vprašanj izobraževanja odraslih, marveč mora biti voljan tudi sredi življenja podvzeti projekte za razvoj ljudi. Vedenja iz andragogike in praktičnega poteka izobraževanja odraslih nudijo tudi fakultete in visoke šole za socialno delo. Socialno-varstvene projekte, ki jih študenti vodijo v okolju, slednji navadno povežejo $\mathrm{z}$ izobraževanjem odraslih. Še več, če vemo, da mnogi ljudje, da pravzaprav "eden od sedmih ljudi potrebuje pomoč«, potem je nedvomno pomembno, da je del te pomoči tudi izobraževanje, ki naj pripomore k temu, da se človek postavi na lastne noge. ${ }^{2}$

Znano je, in na to kažejo tudi

$\mathrm{Na}$ Nizozemskem andragogika ni le veda o izobraževanju odraslif, ampak je tudi veda 0 družbenem razvoju. spoznanja iz »ekonomije družbenih vprašanj ", da socialna varnost in prejemanje socialne pomoči zavirata ustvarjalnost, delavnost in proizvodnost. ${ }^{3}$ Tega se zavedajo tudi na teh šolah. Pomoč, ki jo nudijo ljudem, naj slednjim nudi tudi razvojne možnosti, so prepričani v teh ustanovah. Tako so projekti za ljudi potrebne pomoči navadno, ali zmeraj, tudi izobraževalne narave.

\section{OD IZOBRAŽEVANJA KMETOV V KRAJU DO IZOBRAŽEVANJA PRED UPOKOIITVIJO}

V Driekantu sem se oglasila v času svojega študijskega obiska na Nizozemskem. Prav- 


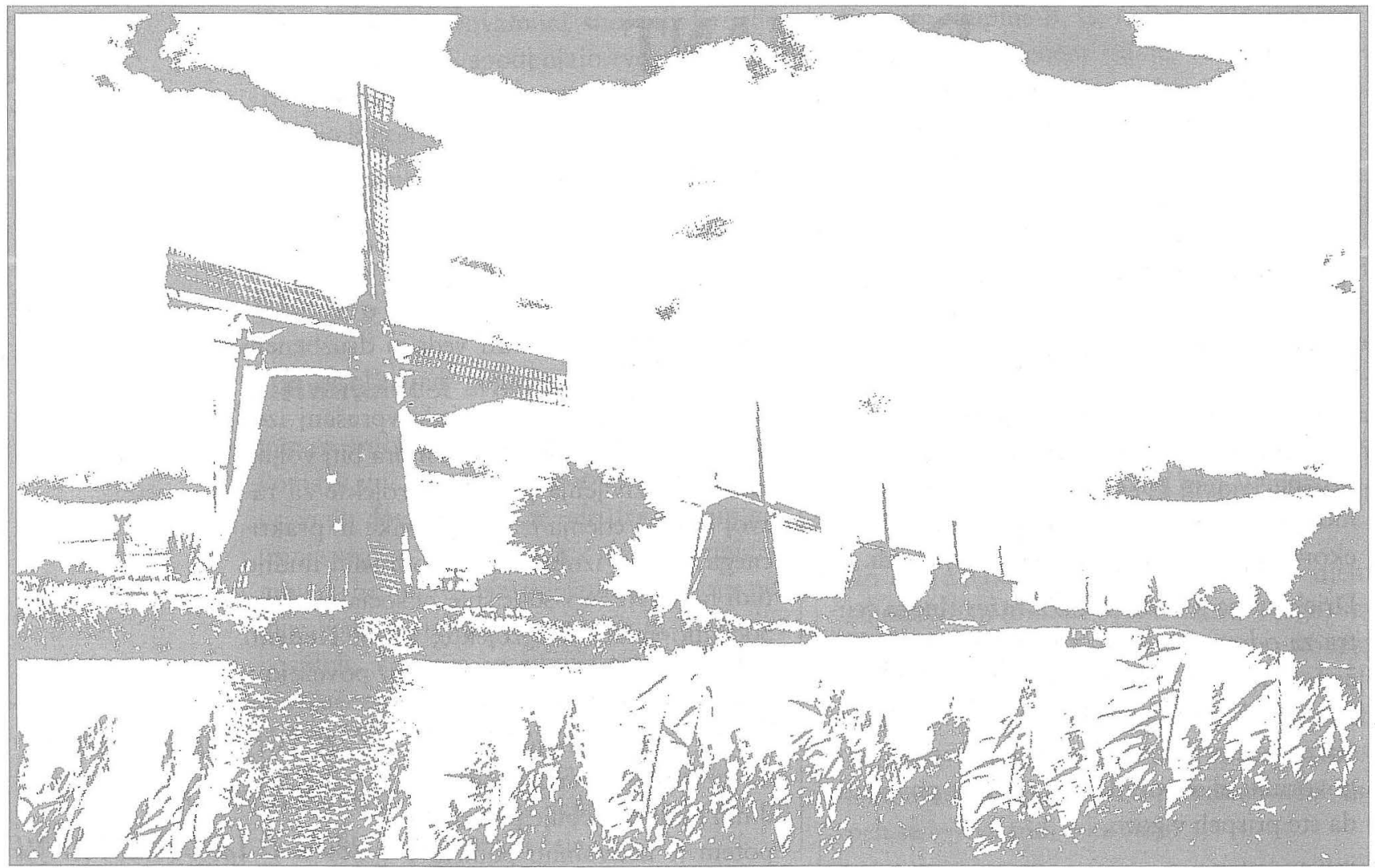

zaprav sem se tja namenila zgolj zato, da se srečam s kolegom izobraževalcem odraslih Jumbom Clerkom. Na Nizozemskem pravijo da je Jumbo »the person « ali tista edina prava oseba, h kateri se stekajo vse poti, kadar je govor o predupokojitvenem izobraževanju.

Zanimivo je, da smo v Sloveniji leta 1984 pričeli z izobraževanjem starejših odraslih, skorajda hkrati pa tudi s prvimi programi predupokojitvenega izobraževanja. Iz teh programov smo kasneje leta 1995 izvedli programe izobraževanja za lokalni razvoj in prve programe izobraževanja v skupnosti ali kot bi rekli na Nizozemskem izobraževalne programe za družbeni razvoj. Na Nizozemskem je bila pot obratna od naše. Leta 1947 , pred nastankom Driekanta, sta se tako združili lokalna Ljudska visoka šola in $\mathrm{Ni}$ zozemska kmetska zveza in nastali so »rezidenčni tečaji« za okoliško prebivalstvo ali tečaji z bivanjem v kraju učenja. Le 1954 je tečaje finančno podprla vlada in pri tem želela, da center pripravi programe za posamezne družbene skupine. Tako so nastali programi za organizacije žensk, programi poklicnega usmerjanja in vodenja, programi, ki so obravnavali življenjska vprašanja ljudi, pa tudi takšni za zdravstveni sektor, denimo za sestre, ki so delale na domovih invalidnih oseb. Leta 1960 je bilo na razpolago le še $70 \%$ državnega denarja, drugo so morali poravnati udeleženci izobraževanja sami. Leta 1984 pa je država svojo denarno podporo pogojila in je postavila svoje prednostne cilje. Tedaj so v Driekantu pričeli razvijati izobraževanje za delavske svete. Leta 1980 je to izobraževanje naravno privedlo do prvih programov predupokojitvenega izobraževanja.

Tako se v Driekantu danes srečujeta dve polji delovanja: (1)izobraževanje za družbeni 
razvoj, kjer teče usposabljanje lokalne oblasti, lokalnih socialno-varstvenih organizacij, izobraževanje za prostovoljstvo, izobraževanje za sodelovanje delavcev v upravljanju, pa tudi izobraževanje starejših delavcev za vrnitev na trg dela ali vzdrževanje zaposljivosti na delovnem mestu in (2) predupokojitveno izobraževanje.

\section{PODOBNOST VPRAŠANJ}

Predstavitev Driekantovih programov predupokojitvenega izobraževanja, ki jih želijo in podpirajo prav vsi, od industrije do ljudi samih, je znova potrdila moje prepričanje, da se ljudje v mestnih okoljih povsod v Evropi srečujejo s precej podobnimi vprašanji takrat, ko preidejo v pokoj; vsi želijo osvestiti prehojeno življenjsko pot in preoblikovati svojo življenjsko filozofijo, če z življenjem niso bili zadovoljni, ali pa si želijo z življenjem preprosto nadaljevati (kar jim okolje pogosto preprečuje). Vsi se sprašujejo, kako naj preživljajo čas in ga strukturirajo sami, na sebi primeren način, kako naj iz poklicne dejavnosti preidejo $\mathrm{k}$ drugim. $\mathrm{Na}$ dalje se sprašujejo, kako naj izboljšajo stike z ljudmi, saj ti znova postanejo zelo pomembni, pa tudi, kako naj uravnovesijo odnose $\mathrm{v}$ družini. Mnogi bi želeli vedeti, kaj pravzaprav pomenita staranje in starost in kakšne nove priložnosti se jim odpirajo. To, kar je v našem okolju drugače, pa je, da v predupokojitvenem programu želimo starejše delavce opozoriti na to, da morajo na svojem delovnem mestu tudi $z$ izobraževanjem ohranjati zaposljivost, da imajo mnoge prednosti, ki naj najdejo mesto tudi v politiki zaposlovanja. ${ }^{4}$ Prav tako želimo, da bi navkljub slabšalnim stereotipom $\mathrm{v}$ okolju razumeli, da upokojitev ni počitek, da morajo s svojim življenjem nadaljevati in poiskati različne možnosti včlenitve $v$ družbo. V našem predupokojitvenem programu, ki ga skupaj pripravljata Gerontološko društvo Slovenije in Univerza za tretje življenjsko obdobje Slove- nije, ne bomo pozabili tudi na družbeno vlogo starejših, kajti le oni se bodo lahko dovolj dobro borili za bolj prosvetljeno obravnavo vprašanja starejših in njihovega dejavnega sožitja z vsemi drugimi rodovi. ${ }^{5}$

mag. Dušana Findeisen

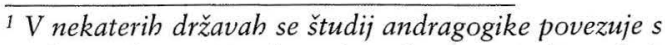
študijem ekonomije, drugod predvsem s študijem kulture. Pa vendar se tudi tam, kjer se na videz zdi, da gre predvsem za nekakšno ločeno ali »čisto « vedo, ni moč izogniti znanj iz ekonomije ali socialnega dela in kulture. Andragogika je veda o izobraževanju odraslih, izobraževanje odraslih pa je neločljivo povezano $z$ delom in življenjem ter razvojem posameznikov in skupnosti.

${ }^{2}$ Le Grand, J., Proppper, C., Robinson, R.: The Economics of Social Problems, 3rd edt., Macmillan, London, 1992.

3 Prav tam, str. 215.

4 Politika zaposlovanja in spremliajoča zakonodaja morata upoštevati prednosti in neprednosti posameznih starostnih skupin delavcev: mladih, srednje starih in starejsih. Le tako se podjetja labko dobro razvijajo in so konkurenčna.

sProgram predupokojitvenega izobraževanja sta v Sloveniji podprla Nizozemski nacionalni inštitut za socialno vasrtvo in Zavod za odprto družbo. 